\title{
LAS REPERCUSIONES DEL PROCESO DE REESTRUCTURACIÓN DEL REAL PATRIMONIO EN VALENCIA SOBRE LA CASA DE MEDINACELI (1814-1837)
}

\section{THE REPERCUSSIONS OF THE RESTRUCTURING PROCESS OF THE REAL PATRIMONIO IN VALENCIA ON THE LINEAGE OF MEDINACELI (1814-1837)}

\author{
Vicente Gómez Benedito \\ IES Alto Palancia (Segorbe)
}

\section{RESUMEN}

Este artículo pretende evidenciar la trascendencia que tuvo la actuación patrimonialista de la Corona sobre las rentas y derechos de los señores valencianos. Tomando como ejemplo la Casa de Medinaceli, se subraya la notable caída de la renta como consecuencia de la pérdida de los derechos privativos en favor del Real Patrimonio. La supresión del carácter monopolístico de tiendas, hornos o molinos, privará a los señores del principal atractivo que permitía alcanzar precios ventajosos en los contratos de arriendo. Pero la política patrimonialista de la Corona no solo afectó a los intereses señoriales, también perjudicó a muchos ayuntamientos y distintos hacendados, que habían conseguido apropiarse de importantes regalías. Por esta razón, durante el reinado de Fernando VII se desarrollará un complejo conflicto con múltiples actores.

Palabras clave: Casa de Medinaceli, Real Patrimonio, Valencia, regalías, renta nobiliaria.

\begin{abstract}
This article seeks to provide evidence of the impact Crown patrimonialist action had on the incomes and rights on the Valencian lords. The example of the Lineage of Medinaceli highlights the significant decline in income experienced as a consequence of the loss of private rights in favour of Patrimonio Real. The suppression of the monopolistic character of shops, bakeries, and mills prevented the lords from reaching advantageous prices regarding lease contracts. The patrimonial policy of the Crown affected not only the lords' interests, but also those of many town councils and assorted landowners, all of whom had managed to appropriate important royalties. This is the reason why, during the reign of Ferdinand VII, a complex conflict with multiple actors will develop.
\end{abstract}

Keywords: Lineage of Medinadeli, Real Patrimonio, Valencia, "regalías" (royalties), noble income. 
Tradicionalmente se ha relacionado el intenso declive de la renta señorial valenciana en el período final del Antiguo Régimen con los movimientos de resistencia y protesta antiseñorial, así como con las dificultades de un buen número de casas nobiliarias para acometer un proceso de reorganización interna que les permitiese afrontar con garantías mínimas un nuevo contexto político y social extremadamente convulso y complejo. La relevancia de estos dos factores es innegable y ha sido suficientemente tratada en la historiografía', reflejando un modelo interpretativo perfectamente válido en el conjunto de la monarquía hispánica, aunque, cuando menos, incompleto para el territorio valenciano, donde la trascendencia de los bienes y derechos patrimoniales de la Corona se muestra como un elemento determinante para entender la evolución de la renta nobiliaria.

Durante decenios la Corona había ido perdiendo paulatina e inexorablemente rentas, bienes y derechos, un proceso que tuvo un punto de inflexión con la llegada al poder de los Borbones. La nueva monarquía puso en marcha al comenzar el siglo XVIII, con mejor o peor fortuna, una política de recuperación de rentas y derechos enajenados en el pasado, buscando ampliar las bases financieras de una Hacienda con continuos problemas de liquidez. Estas actuaciones tuvieron destacada relevancia en el territorio valenciano, donde el Rey había dispuesto desde la época de la conquista de importantes ingresos procedentes de tercios-diezmos, regalías 0 , incluso, sobre estableci-

1 Véanse, entre otros, ARDIT LUCAS, M. (1993): "Señores y vasallos en el siglo XVIII valenciano", en Serrano E. y Sarasa E. (eds.), Señorío y feudalismo en la Península lbérica (siglos XII-XIX), Fdo. el Católico, Zaragoza, vol. II, pp. 249-274; CARRASCO MARTíNEZ, A. (1996): "Modernización o adaptación: los cambios en la administración señorial durante el siglo XVIII", en Anes, G. (coord.), El mundo hispánico en el siglo de la luces, Univ. Complutense, Madrid, vol. I, pp. 557-573; CATALÁ SANZ, J. A. (1995): Rentas y patrimonios de la nobleza valenciana en el siglo XVIII, Siglo XXI, Madrid; PESET, M., GRAULLERA, V. y MANCEBO, M. F. (1987): "Plets, senyories i propietat a la València del segle XVIII", Estudis d'Història Agrària, $n^{\circ}$ 6, pp. 203-239; RUIZ TORRES, P. (1984): "Los señoríos valencianos en la crisis del Antiguo Régimen: una revisión historiográfica", EHCPV, n 5, pp. 23-79; WINDLER, CH. (1995): "Las reformas administrativas de la aristocracia española en el contexto del absolutismo reformista", Historia Social, n² 23, pp. 79-99. 
mientos enfitéuticos de casas y tierras, todo ello conformado en torno al Real Patrimonio.

La actuación patrimonialista de la Corona provocó la reacción del estamento nobiliario en el País Valenciano, al ver peligrar una parte muy importante de sus ingresos, aquellos que tenían como fundamento los derechos privativos, exclusivos y prohibitivos, conocidos como regalías. Pero la nueva dinámica emprendida por el Real Patrimonio no solo afectó a las percepciones señoriales, también repercutió en los intereses de los pueblos y de un grupo no menor de hacendados. Y no solo estamos hablando de poblaciones de realengo, donde los consistorios habían conseguido por distintas concordias, compras o donaciones regias el estanco privilegiado o la libre utilización de algunos derechos y regalías. También de pueblos de señorío, que habían alcanzado el control de determinadas regalías, bien como resultado de donaciones señoriales, que habían tenido su origen en el intento de solucionar graves problemas en la repoblación del territorio o para finiquitar largos y costosos conflictos, o bien por la apropiación fraudulenta de esos derechos a sus señores.
Este enrevesado conflicto de intereses, agudizado por el proceso revolucionario de inicios del siglo XIX, ya fue estudiado profusamente por las profesoras Carmen y Encarna García Monerris², clarificando el marco normativo sobre el que se desarrolló y apuntando el posicionamiento de los diferentes actores. Pero el ámbito de referencia general requiere, en una segunda escala de estudio, de análisis históricos concretos, que permitan observar cómo afectaron las leyes y medidas adoptadas a las distintas poblaciones sobre las que se aplicaron. $Y$ este es el objetivo fundamental del presente trabajo, analizar las repercusiones que el proceso de reestructuración del Real Patrimonio tuvo en un espacio mucho más específico y perfectamente delimitado, el de los estados señoriales valencianos de la Casa de Medinaceli.

\section{ANTECEDENTES: El PROGRAMA INCOR- poracionista de la Corona en el SIGLO XVIII}

La nueva política de incorporación de bienes y derechos enajenados de la Corona, vino acompañada en Valencia de una necesaria reestructuración del Real Patrimonio,

2 GARCÍA MONERRIS, C. (1983): "Fernando VII y el Real Patrimonio (1814-1820): las raíces de la 'cuestión patrimonial' en el País Valenciano", Estudis d'Història Contemporània del País Valencià (EHCPV), n ${ }^{\circ}$ 4, pp. 33-66. GARCÍA MONERRIS, E. (1983): "Real Patrimonio y resistencias antifeudales en el País Valenciano (1834-1843)", EHCPV, n 4, pp. 99-132. GARCÍA MONERRIS, E. y C. (2015): Las cosas del rey. Historia política de una desavenencia (18081874), Akal, Madrid. 
como consecuencia de la abolición foral. La ordenanza de 4 de julio de 1718, por la que se establecía un intendente en cada provincia con total autoridad en los ramos de justicia, policía, hacienda y ejército, permitió asumir al nuevo cargo borbónico las funciones del antiguo Bayle General, englobando la administración del Real Patrimonio en la más general de la Real Hacienda ${ }^{3}$. Sin embargo, esta reorganización administrativa supuso, en principio, un importante desorden y confusión legislativa, ocasión que fue "aprovechada por parte de municipios, de señores feudales y de particulares, para iniciar un proceso de usurpación de terrenos (y derechos) pertenecientes a la Corona" ${ }^{4}$. Tampoco favoreció a la recuperación de bienes la actitud ambigua y vacilante demostrada por la propia Corona, simultaneando decididas medidas patrimonialistas junto con ventas y concesiones de mercedes. Pero los escasos resultados positivos para el Real Patrimonio durante esta primera etapa no solo se explican por los factores mencionados, también fue fundamental el procedimiento marcado para su ejecución. Durante la primera mitad de la centuria imperó la vía judicialista o de lo contencioso, representada por el Consejo de Castilla, donde debía prevalecer la defensa de los intereses de los afectados, aun cuando esta modalidad supusiese un desenlace del proceso muy lento y de inciertos resultados. Frente a este procedimiento, de raíz más antigua, se contraponía una vía administrativa, defendida por el Consejo de Hacienda, que planteaba unos criterios más generalistas y expeditivos ${ }^{5}$.

El reinado de Carlos III planteó una política incorporacionista mucho más decidida, aunque sin resultados sobresalientes. La vía administrativa comenzó asumiendo la iniciativa en la recuperación de rentas y derechos enajenados, pero la respuesta de los fiscales del Consejo de Castilla entorpeció en distintas ocasiones sus actuaciones. No obstante, y aun a pesar de todos los obstáculos y dificultades, se

3 La Ordenanza marcaba expresamente en su artículo 27 que el Intendente debería "ser Juez privativo en todas las dependencias que se ofrecieren de cosas sobre que aya imposicion de censos, feudos, ó otros efectos de Realengo, cuyo dominio directo alodial, ó feudal perteneciere á mi Real hazienda". En Ordenanza de 4 de julio de 1718. Para el establecimiento, e instruccion de Intendentes (1720), Juan de Aritzia, Madrid, pp. 30-31.

4 SANZ ROZALÉN, V. (2000): Propiedad y desposesión campesina. La Bailía de Morella en la crisis del régimen señorial, Fundación Instituto de Historia Social, Valencia, p. 174.

5 Sobre las dos vías incorporacionistas y la tensión político-constitucional que se originó entre ellas, véase GARCÍA MONERRIS, C. y E. (2004): "La Nación y su dominio: el lugar de la Corona", Historia Constitucional, n 5 , pp. 161-190. 
abrió un nuevo camino en la política incorporacionista, de especial significación en Valencia. El 10 de junio de 1760 se firmaba una Real Cédula declarando privativo de la Intendencia el conocimiento de las causas que afectaban al Real Patrimonio en Valencia, evitando la injerencia de otros tribunales perniciosos para los intereses de la Corona. La nueva norma provocó un claro conflicto de competencias en Valencia entre la Real Audiencia, más partidaria de la actitud garantista que planteaba la vía judicialista, y la Intendencia, resolviéndose en favor de esta última.

Ahora bien, una cuestión es que el Tribunal del Real Patrimonio se arrogara la potestad de juzgar los establecimientos de hornos, molinos o almazaras, y otra muy distinta que sentenciara en contra de los intereses de los señores. Branchat cita una larga lista de pleitos resueltos en favor de los señores, justificándose las sentencias en los capítulos de las Cartas Puebla, donde se regulaban los privilegios exclusivos, pri- vativos y prohibitivos de los dueños baronales ${ }^{6}$. En el ámbito de estudio que nos ocupa, el de los señoríos de los Medinaceli, la dinámica no fue muy distinta. En el año 1775 dos particulares solicitaban al Real Patrimonio el establecimiento de sendos hornos en Segorbe, pero la concesión no se ultimaría por la férrea oposición del duque de $\mathrm{Me}$ dinaceli ${ }^{7}$. Similares circunstancias concurrieron en la solicitud para la construcción de un molino harinero en la Pobla de Vallbona ${ }^{8}$. Aunque no siempre los contenciosos fueron propicios para el Duque, como demuestra el conflicto que por las mismas fechas se desarrollaba en la Vall d'Uixó sobre la construcción de una almazara?.

Valorando los logros conseguidos, no podemos calificar de efectiva la política de recuperación de rentas y derechos enajenados de la Corona. Y esta situación empeoraría aún más si cabe en la última década del siglo XVIII, al iniciarse una etapa de inactividad en la Junta Patrimonial, ante la perspectiva

6 BRANCHAT, V. (1784-1786): Tratado de los derechos y regalías que corresponden al Real Patrimonio en el Reino de Valencia, Valencia, J. de Orga, vol. I, pp. 282-283.

7 Cartas del Alcalde Mayor de Segorbe al Contador General de 19 de noviembre de 1775 y 26 de septiembre de 1776. En Archivo Ducal de Medinaceli (ADM), Contaduría General, leg. $49 / 1$.

8 El litigio judicial en Arxiu del Regne de València (ARV), Bailia E, exp. 1184.

9 ARV, Balía E, exp. 1035. 
de una próxima desamortización de los bienes del Real Patrimonio para acudir al creciente endeudamiento de la monarquía. Todas estas circunstancias explican que la actuación patrimonialista de la Corona prácticamente no afectara a las rentas y derechos de la Casa de Medinaceli en Valencia durante el siglo XVIII. Escenario muy distinto se dibujará durante la centuria decimonónica.

\section{El Real Patrimonio como posesión particular del Monarca}

El proceso revolucionario que se inicia en 1808 y las sucesivas reacciones absolutistas provocarán notables consecuencias en el Real Patrimonio. Los diputados de Cádiz, acuciados por las dificultades hacendísticas del momento, declararon al Real Patrimonio como uno más de los bienes nacionales que debería administrar la Junta del Crédito Público, con el objetivo de hacer frente al pago de la elevada deuda nacional ${ }^{10}$. Esta decisión comportaba un cambio fundamental para el Real Patrimonio, tanto en su organización y estructura como en su finalidad, pero la práctica imposibilidad de poner en marcha la propuesta gaditana hizo que su huella sobre la institución fuese más doctrinaria que real. Sería otra disposición de las Cortes de Cádiz la que tendría implicaciones mucho más significativas. Por Real Cédula de 19 de julio de 1813, el gobierno hacía extensivo al Real Patrimonio la supresión de los privilegios exclusivos, privativos y prohibitivos que ya había dictado para los señores feudales en el decreto de abolición de los señoríos de agosto de 1811 . La nueva ley permitía a los poseedores de hornos, molinos y otros artefactos censidos a la Corona, alcanzar el dominio directo sobre sus propiedades y evitar el pago de censos enfitéuticos. Pero, más importante era la libertad que confería para poder constituir en lo sucesivo cualquier tipo de empresa sin necesidad de obtener establecimiento. La nueva legislación eliminaba de un plumazo uno de los ingresos más importantes del patrimonio regio en Valencia, el que producían las regalías.

¿Cómo afectó la desaparición de los derechos privativos a los intereses del Duque en Valencia? La salida de las tropas francesas en julio de 1813 y la constitución de los nuevos ayuntamientos provisionales un mes después, hicieron coincidir

10 El decreto de 13 de septiembre de 1813 sobre clasificación y pago de la deuda nacional, incluía en su artículo XVII a "las alhajas y fincas llamadas de la Corona" como una de las fincas de hipoteca especial para el pago de la deuda nacional. En Coleccion de los Decretos y Órdenes que han expedido las Córtes Generales y Extraordinarias desde... (1820), Imprenta Nacional, Madrid, tomo IV, pp. 258-259. 
en el tiempo la publicación de la Ley de Señoríos de 1811 en los pueblos valencianos con la Real Cédula sobre la supresión de los derechos privativos del Real Patrimonio de julio de 1813. La Ley de Señoríos ya había regulado en su artículo séptimo la supresión de los derechos privativos y exclusivos en los pueblos de señorío, lo que permitía la libre instalación y apertura de molinos, hornos u otros "artefactos" por parte de cualquier vecino. Pero, aun a pesar de la claridad con que se manifestaba la ley para las zonas de señorío, en el País Valenciano el dominio del Real Patrimonio sobre ese tipo de establecimientos, bien fuese en tierras de realengo o de señorío, no ofrecía las suficientes garantías a los interesados sobre la completa libertad en la constitución de los nuevos artefactos, incertidumbre que desaparecería con la Real Cédula de julio de 1813. Las consecuencias de la nueva legislación fueron inmediatas y considerables. En la mayor parte de los pueblos valencianos pertenecientes a los Medinaceli se presentaron un im- portante número de solicitudes en los ayuntamientos para la construcción de nuevos artefactos, dándose algunos casos singulares, como Segorbe, donde las peticiones fueron incluso anteriores a la publicación por el consistorio de la Real Cédula, lo que da prueba del interés y capacidad de determinadas personas para sacar provecho de la nueva situación jurídica ${ }^{11}$.

El nuevo escenario tuvo un escaso recorrido temporal, puesto que la restauración absolutista de Fernando VII pronto fijó su atención en el Real Patrimonio. El 22 de mayo de 1814 el Rey firmaba un Real Decreto por el que se restablecía "la Mayordomía mayor de Casa Real, para que entienda en todo lo relativo á ella, separando enteramente el gobierno é interes de esta de los demas del Estado"12. El proyecto del monarca era nítido, crear un patrimonio particular. Pero la nueva organización administrativa de los bienes y derechos particulares del rey no supuso un aumento de las rentas percibidas, debido a la "dilacion que han sufrido hasta el

11 De las diez solicitudes que se presentaron en el Ayuntamiento de Segorbe para construir nuevos molinos y hornos, cinco de ellas se registraron entre los días 31 de agosto y el 22 de septiembre, cuando la ley no se haría pública en sesión consistorial hasta el día 4 de octubre. Las solicitudes y la sesión del Ayuntamiento en Archivo Municipal de Segorbe (AMS), leg. 3015/50, fols. 1813/21-31.

12 En MARTíN DE BALMASEDA, F. (1818): Decretos del rey don Fernando VII, Imprenta Real, Madrid, t. I, pp. 20-21. 
dia las controversias judiciales, de las disputas frecuentes que se han suscitado con otras Autoridades"13, por lo que se hacía cada vez más necesario dotar de jurisdicción privativa y exclusiva a la nueva estructura organizativa del Real Patrimonio, evitando así las interferencias y perjuicios que podían ocasionar otros tribunales de justicia u órganos de gobierno sobre los intereses patrimoniales del monarca. De esta forma, el 9 de agosto de 1815 se creaban la Junta Gubernativa y la Junta Suprema Patrimonial de Apelaciones $^{14}$. Por la primera, básicamente de carácter asesor, se buscaba agilizar la tramitación de expedientes y la recuperación de rentas y derechos. Mucho más importante era la segunda, que perseguía evitar las apelaciones a otros tribunales de justicia que no fuese la Junta Suprema, cuando se tratasen asuntos concernientes a los bienes y derechos del monarca. Teniendo en cuenta que ambas instituciones estaban presididas por la misma persona, podemos entender la relevancia del poder con el que se le había dotado, al constituirse como juez y parte en todos los trámites y pleitos que afectaran al Real Patrimonio valenciano.

Reforzada su estructura administrativa y amparadas las decisiones por su jurisdicción privativa, el Real Patrimonio inició un período mucho más decidido y ambicioso en la recuperación de rentas y derechos a partir del año 1816. Por una Real Orden de junio de 1816, se ordenaba al nuevo Baile valenciano la resolución progresiva de los más de 3.000 expedientes abiertos en la época de Canga Argüelles sobre recuperación de derechos del Real Patrimonio y paralizados en abril de 1807 por Godoy ${ }^{15}$, una medida más efectista que práctica como de-

13 Del preámbulo justificativo a la creación de las Juntas Gubernativa y de Apelaciones. En MARTíN DE BALMASEDA, F. (1819): Decretos del rey don Fernando VII, Imprenta Real, Madrid, t. II, p. 549.

14 En MARTíN DE BALMASEDA, F. (1819), op. cit., t. II, pp. 549-551.

15 En el año 1806, Canga Argüelles, nuevo Contador del Real Patrimonio, ponía en marcha el arriendo de las Bailías valencianas, como medio para mejorar los ingresos. La efectividad de la nueva medida precisaba de la previa actualización de los derechos y rentas, por lo que se obligó al reconocimiento del dominio directo de todos aquellos que tuviesen bienes usurpados del Real Patrimonio. La actuación patrimonialista llevó a la incoación de más de 3.000 expedientes, aunque, finalmente, los intereses particulares de un círculo de individuos muy próximos al poder y del mismo Godoy llevaron a la paralización en el año 1807 de esta enérgica política de recuperación de rentas. Para un análisis detallado de las repercusiones de la política de arriendo de la Bailías valencianas en los dominios de los Medinaceli, véase GÓMEZ BENEDITO, V. (2015): Declive y liquidación de los dominios valencianos de la Casa de Medinaceli, tesis doctoral, Universitat Jaume I, Castelló, pp. 713-720. 
muestran los escasos resultados obtenidos, al menos en los dominios valencianos de los Medinaceli, donde no se recuperaron por el Real Patrimonio ni uno solo de los bienes o derechos reclamados al Duque. Mucho más resolutivo fue el programa para regularizar todos los molinos, hornos y otros artefactos que vimos se habían constituido libremente con motivo de la promulgación de la Real Cédula de 19 de julio de 1813. Cabe precisar que la legislación liberal sobre la supresión de los derechos privativos y exclusivos se había mantenido tras la restauración absolutista en lo referente a los señoríos, pero no en el Real Patrimonio. Los individuos que habían construido diferentes artefactos en la época constitucional se vieron en la obligación de solicitar un suplemento de títulos si no querían perder su propiedad, convirtiéndose en enfiteutas del Real Patrimonio.

La tabla adjunta permite observar el número de establecimientos acogidos a la regularización que planteó el Real Patrimonio durante estos primeros años, incluyéndose también las nuevas solicitudes ges- tionadas. Entre los años 1816 y 1819 se solicitaron 35 suplementos de títulos para molinos, hornos, almazaras o pilones de carnicería, a los que habría que unir otras 16 peticiones de nuevos establecimientos. Sobre estas cifras es necesario realizar dos consideraciones. En primer lugar, no todos los establecimientos carentes de la oportuna licencia y autorización se presentaron ante el Real Patrimonio, como demuestran el listado de propietarios que desde el año 1825 se vieron obligados a firmar suplementos de títulos con el patrimonio regio ${ }^{16}$. En segundo lugar, el elevado número de nuevos enfiteutas censidos al Real Patrimonio no resulta excepcional ni distinto a lo que estaba ocurriendo en la mayor parte del territorio valenciano ${ }^{17}$.

La regularización de establecimientos con el Real Patrimonio permitió descubrir la importancia que habían llegado a tener los molinos, hornos y otro tipo de establecimientos constituidos libremente, no solo durante la época constitucional, también durante los años anteriores, evidenciando los escasos resul-

16 Cabe precisar que a partir de 1825, la oposición del Duque a los establecimientos hizo que se delegaran mucho las sentencias del Real Patrimonio y en algunos casos no llegaran ni a concluirse los pleitos.

17 Carmen García Monerris contabiliza en el País Valenciano 929 nuevos establecimientos con el Real Patrimonio entre los años 1816 y 1819 . Si en esas fechas los establecimientos en los dominios valencianos de los Medinaceli alcanzaron la cifra de 51, quiere decir que supusieron el 5,5\%, una proporción no muy distinta a la que representa la población en esos territorios. Los datos para el País Valenciano en GARCÍA MONERRIS, C. (1983), op. cit., p. 54. 
Establecimientos acogidos a la regularización que planteó el Real Patrimonio a partir de 1815

\begin{tabular}{|c|c|c|c|c|}
\hline Enfiteuta & Población & Propiedad censida & Carácter & Fecha concesión \\
\hline J. Royo y P. Vicente & Segorbe & Un molino & Supl. títulos & $15-05-1816$ \\
\hline Pascual Calatayud & Suera & Un horno & Supl. títulos & $15-05-1816$ \\
\hline Bernardo Montón & Benaguasil & Un molino & Supl. títulos & $15-05-1816$ \\
\hline José Ignacio Abargues & Beniarjó & Un horno & Supl. títulos & $15-05-1816$ \\
\hline José Ignacio Abargues & Beniarió & Un molino & Supl. títulos & $15-05-1816$ \\
\hline Juan Bta. Giner & Pobla Vallbona & Un horno & Supl. títulos & $15-05-1816$ \\
\hline José Mascarell & Ador & Un horno & Supl. títulos & $15-05-1816$ \\
\hline Pascual Fuster & Aín & Un molino & Supl. títulos & $15-05-1816$ \\
\hline Pascual Belloc & Benaguasil & Un horno & Supl. títulos & $15-05-1816$ \\
\hline Antonio Arnau & Segorbe & Un molino & Supl. títulos & $17-05-1816$ \\
\hline Vicente Martín & Suera & Un horno & Supl. títulos & $24-05-1816$ \\
\hline Francisco Soriano & La Vall d'Uixó & Pilón de carnice. & Supl. títulos & 23-10-1816 \\
\hline Juan y Fco. Monfort & Fanzara & Un horno & Supl. títulos & $30-10-1816$ \\
\hline José Carrioz & Chiva & Un molino & Supl. títulos & $12-11-1816$ \\
\hline José Former & Chiva & Un horno & Supl. títulos & $12-11-1816$ \\
\hline Juan Bta. Martí & Chiva & Un horno & Supl. títulos & $12-11-1816$ \\
\hline José Ribelles & Segorbe & Un molino & Supl. títulos & $12-11-1816$ \\
\hline Ramón Durbá & Segorbe & Un horno & Supl. títulos & $12-11-1816$ \\
\hline Francisco Herrero & Fondenguilla & Un molino & Supl. títulos & $12-11-1816$ \\
\hline Cristóbal Izquierdo & Aín & Un molino & Supl. títulos & $12-11-1816$ \\
\hline Antonio Hernández & Benaguasil & Pilón de carnice. & Supl. títulos & $12-11-1816$ \\
\hline Matías Carpí & El Verger & Un horno & Supl. títulos & $07-12-1816$ \\
\hline Josefa Furió & Segorbe & Terrenos & Nuevo establec. & $06-01-1817$ \\
\hline J. Royo y P. Vicente & Segorbe & Un molino & Nuevo establec. & $18-02-1817$ \\
\hline Hermanos Alayrach & Geldo & Un molino & Nuevo establec. & $24-02-1817$ \\
\hline Antonio Gil & Godelleta & Un horno & Supl. títulos & $24-02-1817$ \\
\hline Francisco Hernández & Chiva & Un horno & Supl. títulos & $21-03-1817$ \\
\hline María Antonia Andrés & Chiva & Un horno & Supl. títulos & $21-03-1817$ \\
\hline Vicenta Carlos & Chiva & Un horno & Supl. títulos & $21-03-1817$ \\
\hline Vicenta Hernández & Chiva & Un horno & Supl. títulos & $21-03-1817$ \\
\hline Pascual Monfort & Fanzara & Un molino & Nuevo establec. & $11-04-1817$ \\
\hline Convento Carmelitas & Pobla Vallbona & Un molino & Supl. títulos & 15-04-1817 \\
\hline Manuel Clemente & Segorbe & Un horno & Supl. títulos & $03-06-1817$ \\
\hline José Navarro & Segorbe & Un molino & Nuevo establec. & 14-11-1817 \\
\hline Manuel Clauisch & Segorbe & Un horno & Supl. títulos & $14-11-1817$ \\
\hline Antonio Arnau & Segorbe & Molino martinete & Nuevo establec. & $14-11-1817$ \\
\hline $\begin{array}{l}\text { Francisco Gallego } \\
\text { Manuel Royo }\end{array}$ & $\begin{array}{l}\text { Segorbe } \\
\text { Segorbe }\end{array}$ & $\begin{array}{l}\text { Pilón de carnice. } \\
\text { Pilón de carnice. }\end{array}$ & $\begin{array}{l}\text { Nuevo establec. } \\
\text { Nuevo establec. }\end{array}$ & $\begin{array}{l}03-03-1818 \\
24-04-1818\end{array}$ \\
\hline Valentín Figueras & Beniarió & Un horno & Supl. títulos & $08-05-1818$ \\
\hline Francisco Rodríguez & El Verger & Una almazara & Supl. títulos & $07-07-1818$ \\
\hline Guillermo Fillol & El Verger & Una almazara & Supl. títulos & $07-07-1818$ \\
\hline
\end{tabular}




\begin{tabular}{|c|c|c|c|c|}
\hline Luis Pérez & El Verger & Una almazara & Supl. títulos & 07-07-1818 \\
\hline Félix Fajardo & Segorbe & Un horno & Nuevo establec. & $21-08-1818$ \\
\hline José Arnau & Segorbe & Un horno & Nuevo establec. & $21-08-1818$ \\
\hline Vicente Tort & Segorbe & Un molino & Nuevo establec. & $21-08-1818$ \\
\hline Cristóbal Bolufer & Xàbia & Aguas & Nuevo establec. & 28-01-1819 \\
\hline Manuel Cebrián & Segorbe & Un molino & Supl. títulos & 09-03-1919 \\
\hline José Marqués & & Molino papelero & Nuevo establec. & $06-04-1819$ \\
\hline Francisco Galindo & Chiva & Un molino & Nuevo establec. & 02-06-1819 \\
\hline Francisco Galindo & Chiva & $\begin{array}{l}\text { Una fábrica de } \\
\text { palo de campeche }\end{array}$ & Nuevo establec. & 02-06-1819 \\
\hline Hermanos Alayrach & Segorbe & Tierras & Nuevo establec. & 17-08-1819 \\
\hline Pedro Esteva & Chiva & Un horno & Supl. títulos & $30-03-1825$ \\
\hline Mateo Martínez & Segorbe & Tierras & Nuevo establec. & 12-04-1825 \\
\hline J. Pascual y J. Aguilar & Segorbe & Tierras & Nuevo establec. & $09-05-1825$ \\
\hline Mariano Miravet & Veo & Una almazara & Supl. títulos & $30-04-1826$ \\
\hline Vicente Domínguez & Benaguasil & Un horno & Supl. títulos & $20-06-1826$ \\
\hline Vicente Maicas & Segorbe & Tierras & Nuevo establec. & $27-08-1827$ \\
\hline Ayto. de Segorbe & Segorbe & Seis tiendas & Nuevo establec. & $21-06-1828$ \\
\hline Ayto. de Segorbe & Segorbe & Dos panaderías & Nuevo establec. & $21-06-1828$ \\
\hline José Rodrigo & Chiva & Un horno & Supl. títulos & $11-11-1828$ \\
\hline Severo Polo & Segorbe & Tierras & Nuevo establec. & $18-11-1828$ \\
\hline José Escrich & Segorbe & Una almazara & Nuevo establec. & $22-09-1830$ \\
\hline José lbáñez & Segorbe & Pilón de carnice. & Nuevo establec. & 20-05-1831 \\
\hline José Barceló & Suera & Una almazara & Supl. títulos & $17-11-1832$ \\
\hline Ayto. de Benaguasil & Benaguasil & Tres tiendas & Nuevo establec. & sin concluir \\
\hline Ayto. de Eslida & Eslida & Tienda-taberna & Nuevo estable. & sin concluir \\
\hline Ayto. de Segorbe & Segorbe & Alhóndiga granos & Nuevo establec. & sin concluir \\
\hline $\begin{array}{l}\text { Ayto. de la Vall } \\
\text { d'Uixó }\end{array}$ & La Vall d'Uixó & Dos alhóndigas & Supl. títulos & sin concluir \\
\hline Ayto. de Segorbe & Segorbe & Cántaro y romana & Nuevo establec. & sin concluir \\
\hline $\begin{array}{l}\text { Ayto. de la Vall } \\
\text { d'Uixó }\end{array}$ & La Vall d'Uixó & Cántaro y romana & Supl. títulos & sin concluir \\
\hline Ayto. de la Pobla & Pobla de Vallb. & Cántaro y romana & Nuevo establec. & sin concluir \\
\hline Ayło. de Benaguasil & Benaguasil & Cántaro y romana & Nuevo establec. & sin concluir \\
\hline Ayto. de Eslida & Eslida & Tierras (alcornoc.) & Supl. títulos & sin concluir \\
\hline Antonio Arnau & Segorbe & Tierras y molino & Nuevo establec. & sin concluir \\
\hline Vicente Manzana & Eslida & Terrenos & Nuevo establec. & sin concluir \\
\hline Manuel García & Chiva & Pilón de carnice & Supl. títulos & sin concluir \\
\hline Ayto. Palma y Ador & Ador & Un horno & Supl. títulos & sin concluir \\
\hline Ayto. Palma y Ador & Ador & Un horno & Supl. títulos & sin concluir \\
\hline Ayto. Palma y Ador & Palma & Un horno & Supl. títulos & sin concluir \\
\hline
\end{tabular}

Los datos de 1816 a 1819 en ARV, Bailía, Libros, $n^{\circ}$ 1525-1527. El resto en cada uno de los expedientes: ARV, Bailía E, exp. 2536, 3210, 3214,3221 y 3447; ARV, Bailía E, Apéndice, exps. 587, 597, 672, 689, 786, 787, 793, 818, 1119,1183 y 1252. 
tados que había cosechado el control de las regalías por parte de los señores baronales pero también del propio Real Patrimonio. Un escenario que comenzará a cambiar con muchísima rapidez, aunque no en beneficio de los señores.

La nueva orientación adoptada por el Real Patrimonio a partir de la primera restauración absolutista supuso para la nobleza valenciana la apertura de un segundo frente en su lucha por preservar sus propiedades y derechos. Las casas señoriales ya no solo debían temer las acciones y pretensiones de los pueblos, ahora era el propio rey quien se había convertido en un duro e implacable competidor por una serie de derechos considerados hasta ese momento por el estamento nobiliario como legítimos, incontestables e imprescriptibles. ¿ Cómo iban a responder ante semejante desafío? ¿se enfrentaría abiertamente la nobleza a la política planteada por Fernando VII de acrecentar a su costa un patrimonio con intereses claramente privados? La pregunta es puramente retórica, porque aun cuando en la cuestión del patrimonio regio la política practicada por Fernando VII había sido mucho más gravosa para las casas señoriales que la adoptada por las propias Cortes de Cádiz, la nobleza valenciana seguía teniendo como aliado natural e insustituible a un monarca absoluto que le preservaba una posición social privilegiada. En consecuencia, la contestación no pasó de la mera suplica, intentando revertir un proceso que, como en el año 1806, hacía peligrar una de las principales fuentes de ingresos de las casas señoriales valencianas, los derechos privativos y exclusivos.

El 8 de mayo de 1818, la Diputación de la Grandeza de España elevaba una Representación al monarca para darle a conocer la delicada situación por la que atravesaban las casas nobiliarias, como resultado de los numerosos pleitos de incorporación en los que estaban implicadas y la pertinaz negativa de muchos pueblos a pagar las rentas señoriales y a reconocer sus derechos. Pero el memorial tenía una cuestión destacada, significar la "persecución que están experimentando los Grandes que tienen Estados y fincas en el Reino de Valencia, por el Intendente y Junta del Real Patrimonio". La nobleza valenciana protestaba contra la reactivación de los expedientes que se habían iniciado en 1806 y buscaba el favor real para paralizarlos de nuevo, como había hecho Godoy en 180718. La demanda de la nobleza no sería contemplada, aunque debemos recordar que esta cuestión ni llegó a tener trascendencia práctica

18 La Representación de la Grandeza ante el Rey de 8 de mayo de 1818 ha sido analizada en GARCÍA MONERRIS, C. (1983), op. cit., pp. 60-64. 
sobre los intereses señoriales, ni derivaría en nuevas y mayores contestaciones del estamento nobiliario.

Muy diferente fue la evolución de los acontecimientos y la respuesta de las casas nobiliarias en la regularización de los artefactos constituidos libremente durante la época constitucional y la solicitud de nuevos establecimientos al Real Patrimonio a partir del año 1814. Ya sabemos que la Ley de Señoríos de 1811 suprimió los derechos privativos en las tierras de señorío, pero las casas nobiliarias con intereses en Valencia nunca renunciaron a ellos. En concreto, la Casa de Medinaceli justificó que los derechos privativos formaban parte de los señoríos territoriales y solariegos, no debiendo ser entendidos como suprimidos, condición que solo afectaba a los señoríos jurisdiccionales. La argumentación jurídica era muy discutible, pero la casa ducal siempre mantuvo su posicionamiento, llegando a conseguir que en el cobro de las prestaciones atrasadas de los años 1813 y 1814 para Segorbe, la Sierra de Eslida y El Verger se incluyeran las rentas provenientes de las regalías ${ }^{19}$. Este mismo discurso se defendió en todas y cada una de las peticiones de suplemento de títulos o nuevos establecimientos ante el Real Patrimonio.

En las instrucciones para la formalización de los nuevos estable- cimientos con el Real Patrimonio se estipulaba la presencia de las partes afectadas. Por esta razón, en todas las solicitudes que concernían a los dominios valencianos de los $\mathrm{Me}$ dinaceli se personó la casa ducal. Resulta destacable la perseverancia del Duque en la incorporación y seguimiento de todos y cada uno de los expedientes, cuando tenía perfecto conocimiento de la evolución de los procesos y la certeza de su desenlace final, siempre adverso a sus intereses. Los expedientes se sustanciaban en primera instancia por vía gubernativa ante el Real Patrimonio, conociéndose de antemano el resultado favorable a los intereses patrimoniales del monarca. Y no era diferente el siguiente trámite, puesto que las apelaciones a la decisión del Real Patrimonio se dirimían en Madrid ante la Junta Suprema Patrimonial de Apelaciones, y pocas sorpresas podían haber cuando quien decidía era juez y parte.

\section{Molinos, hornos y almaza- ras.}

Los establecimientos predominantes y a los que la casa ducal en más ocasiones tuvo que oponerse fueron los referidos a la constitución de molinos, hornos y almazaras. Tanto en este tipo de litigios como en la mayoría de los que afectaban a sus propiedades y derechos, el Duque siempre había fundamen-

19 Sobre esta cuestión véase GÓMEZ BENEDITO, V. (2015), op. cit., pp. 608-612. 
tado sus posiciones en la legitimidad de las donaciones reales y en las Cartas Pueblas firmadas tras el extrañamiento morisco. Pero tras la Ley de Señoríos de 1811 y las posteriores reales cédulas de 15 de septiembre de 1814 y 15 de agosto de 1823 , se hacía muy difícil mantener jurídicamente los derechos privativos bajo el dominio señorial, por lo que debieron buscarse nuevas estrategias de defensa. En el caso de los hornos y almazaras se apeló a cuestiones de carácter más local, como eran la reglamentación sobre la disposición de las construcciones o los trastornos que los nuevos artefactos podían ocasionar al conjunto de la población. En Chiva, para evitar las nuevas instalaciones de hornos, la casa ducal argumentó en sucesivas ocasiones el incumplimiento de la normativa sobre la distancia entre los diferentes establecimientos y el notorio peligro de incendios que para la Villa suponía tener tantos hornos de leña ${ }^{20}$. Y lo cierto es que el número de hornos en esta población era excesivo. Un expediente de reclamación de uno de los enfiteutas del Real Patrimonio, nos permite conocer como en la villa existían seis hornos al comienzo del Sexenio Absolutista, dos de ellos del Duque y los otros cuatro censidos al Real Patrimonio. Pero en muy poco tiempo llegaron a instalarse otros ocho hornos, todos ilegales, aunque posteriormente algunos regularizarían su situación con el Real Patrimonio ${ }^{21}$. En la población de Suera, el pretexto para impedir el suplemento de títulos de una almazara fueron los trastornos y molestias que podía reportar el artefacto a la iglesia de la población, "por el humo que expedirá el hornillo y el hedor que exhalará la inmundicia de las heces" 22 .

Junto a esta batería de razonamientos, poco efectivos, los abogados de la casa ducal no olvidaron plantear otros que afectaban al carácter mismo de la propiedad. El Duque argumentaba que todas sus baronías valencianas se podían conceptuar como señoríos territoriales y solariegos, disponiendo de la propiedad eminente y directa so-

20 La casa ducal alegaba que entre los hornos debía haber una distancia de sesenta casas, norma que incumplían todas las solicitudes. Pero, como se encargaron de recordar los abogados de los afectados, esta normativa solo atañía a la ciudad de Valencia. Sobre esta cuestión véanse las solicitudes de suplementos de títulos en Chiva de Pedro Esteve y José Rodrigo, en ARV, Bailía E, Apéndice, exps. 597 y 787.

21 La situación llegó a tal extremo que en 1833 el Real Patrimonio obligó a emitir un bando al Alcalde Mayor de la villa en el que se prohibía a los vecinos la utilización de los hornos no establecidos al Real Patrimonio o propiedad del Duque, bajo la multa de 25 libras. En ARV, Bailía E, Apéndice, exp. 1248.

22 En ARV, Bailía E, Apéndice, exp. 786; cita en fol. 12r. 
bre el territorio. En consecuencia, aunque los interesados en constituir los establecimientos con el Real Patrimonio mantuviesen el dominio útil de los terrenos, precisaban de la licencia del señor, autorización que el Duque no estaba dispuesto a conceder. Pero tampoco esta argumentación cosechó mejores resultados para la casa ducal. $\mathrm{Ni}$ el recurso ante la Real Audiencia de Valencia, buscando el conflicto entre diferentes tribunales, como había ocurrido en épocas no muy lejanas. La apelación ante la Junta Suprema en Madrid abortaba cualquier posibilidad de éxito. Ante semejante cúmulo de dificultades y limitaciones, no parece insólito que en algunas ocasiones la casa ducal abandonase el litigio, como en la solicitud ante el Real Patrimonio de un horno en Segorbe, en la que tras un dilatado proceso y las escasas perspectivas de éxito, la Contaduría Mayor en Madrid comunicaba a su homónima de Valencia que "no estimaba conveniente mezclarse en negocios de esta naturaleza y el tribunal resuelva lo que estime mas procedente" 23 .

\section{Tiendas, tabernas, pana- derías y carnicerías.}

Mucho más complejo acabó sien- do el proceso en el que se vieron envueltas las tiendas señoriales y otros establecimientos como tabernas, panaderías y carnicerías. Y no tanto por las dificultades encontradas por la casa ducal, que no fueron muy diferentes de las vistas para hornos o molinos, como por la confrontación de intereses entre el Real Patrimonio y el propio gobierno central. El 26 de diciembre de 1818 el Ministerio de Hacienda promulgaba una Real Orden que daba a los pueblos la posibilidad de abrir tiendas para vender al por menor aceite, carne, aguardiente, vinagre y vino, con el objetivo de poder arrendarlas y obtener las rentas que les permitieran complementar los recursos propios para afrontar la nueva contribución genera ${ }^{24}$. La Orden tenía una clara finalidad hacendística, al permitir a los ayuntamientos la instalación de estancos en algunos productos, pero también ordenaba la libertad de venta al por menor del resto de productos y para la totalidad de los expedidos al por mayor. Ninguna de estas iniciativas podía ser vista con buenos ojos por el Real Patrimonio, que había establecido tiendas a diferentes individuos y que rápidamente exigieron la rebaja del canon estipulado o la rescisión de la escritura de establecimiento. La Junta Patrimonial de Valencia protestó

23 El litigio se había iniciado en el año 1828, con la solicitud de suplemento de títulos por Manuel Clemente, y el 2 de julio de 1832 la Contaduría de Madrid comunicaba su decisión a Valencia para que se retirase del proceso. En ARV, Bailía E, exp. 3447, la cita literal en fol. 32r.

24 En MARTíN DE BALMASEDA, F. (1819), op. cit., t. V, pp. 708-710. 
airadamente ante el gobierno de Madrid, consiguiendo que permaneciesen ilesos los derechos del Real Patrimonio, lo que le permitió continuar "en la facultad de establecer ó arrendar como hasta ahora" 25 . Sin embargo, unas nuevas instrucciones del Ministerio, dispuestas en la Real Orden de 18 de junio de 1819, no contemplaron las prerrogativas y excepciones del Real Patrimonio valenciano, concediéndose de nuevo la regulación de tiendas por los pueblos y una limitada libertad de comercio interior ${ }^{26}$.

Las consecuencias prácticas de la nueva legislación no tardaron en presentarse. El 1 de septiembre de 1819 se convocaba en Segorbe una Junta General de Vecinos para decidir si se establecían puestos públicos para la venta al por menor de las referidas cinco especies o si, por el contrario, se decidía su desestanco. Y los segorbinos acordaron establecer dos tiendas para la venta de aguardiente y otras dos para el vinagre, dejando libres la venta de carne, vino y aceite, decisión tomada "con la circunstancia de que el ayuntamiento tiene preparada solicitud de establecimiento por el Real Patrimonio de quatro tiendas de aceyte y abaceria y otras quatro tabernas" ${ }^{\prime 27}$. Para entender por qué el consistorio segorbino no decidió aprovechar la ocasión y estancar en su propio beneficio las cinco especies o productos permitidos, debe observarse que ya se había producido un intento anterior, paralizado por la respuesta del Real Patrimonio $^{28}$. ¿Era el acuerdo del consistorio segorbino un documento

25 Por decreto de 3 de marzo de 1819 el monarca mantenía la normativa de 26 de diciembre de 1818, aunque marcando la excepcionalidad para sus posesiones y derechos de la antigua Corona de Aragón. En ARV, Bailía, Libros, n 4, fol. $215 \mathrm{v}$.

26 La Real Orden 18 de junio de 1819 era, en realidad, una compilación de trece artículos que clarificaban la norma de diciembre de 1818, destacándose que la decisión de constituir las tiendas no debía ser de los ayuntamientos, sino de los pueblos reunidos cada año en Consejo Abierto. En MARTíN DE BALMASEDA, F. (1823): Decretos del rey don Fernando VII, Imprenta Nacional, Madrid, t. VI, pp. 265-268.

27 En AMS, 3016/51, fol. $341 \mathrm{v}$.

28 El 6 de febrero de 1819 el Ayuntamiento de Segorbe había acordado la apertura de cuatro tiendas para la venta de aceite y vinagre y otras tantas tabernas, además de dos puestos de aguardiente de vino, dejando de momento suspendida la apertura de carnicerías, por estar ya contratado el abasto hasta final de año. Los proyectos del consistorio segorbino quedaron paralizados con la publicación de la Real Orden de 3 de marzo de 1819, remarcado por el ejemplo de la localidad de Viver, donde una orden del Baile General de 23 de abril de 1819 prevenía al Ayuntamiento que solo podían abrir tiendas o tabernas aquellas personas establecidas por el Real Patrimonio. En AMS, 3016/51, fol. 305. 
de calculada ambigüedad, manteniendo abierta cualquier solución, o simplemente el producto del desconcierto? Cualquiera que sea la respuesta a esta cuestión, lo cierto es que la decisión nacía de las contradictorias leyes dictadas desde la lejana Madrid para intentar cuadrar el círculo: liberalizar el comercio interior y mantener los privilegios del Real Patrimonio en los antiguos territorios de la Corona de Aragón.

La respuesta de la casa ducal a las dos iniciativas del Ayuntamiento de Segorbe fue inmediata, tanto la de estancar por su cuenta varios productos como la de establecer las otras tiendas y tabernas con el Real Patrimonio. El Duque se negó rotundamente a ambas propuestas, aunque los conflictos no llegaron prácticamente ni a iniciarse. En el fracaso del estanco por el consistorio del aguardiente y vinagre no conocemos las circunstancias acontecidas, aunque presumimos que debieron estar relacionadas con el triunfo del Trienio Liberal y la paralización de la legislación aprobada por el gobierno absolutista. En cuanto a las solicitudes de establecimiento de tiendas con el Real Patrimonio, la
Contaduría Patrimonial se encargó de denegarlas con la justificación de pretenderse el carácter exclusivo, al demandarse por el consistorio "que en ningun otro parage se pueda vender de los generos comprendidos en tiendas establecidas" 29 . Esta última decisión resulta cuando menos paradójica, tanto porque la solicitud del Ayuntamiento se ajustaba al articulado de la Real Orden de 18 de junio de 181930, como porque el dictamen de la Contaduría Patrimonial remarcaba la abolición de los privilegios exclusivos cuando ella misma pedía su mantenimiento para el Real Patrimonio. Por otra parte, utilizaba el concepto de libertad para fundamentar su resolución, obviando su pretensión de arrogarse la potestad de decidir sobre los establecimientos $^{31}$. En realidad, el Real Patrimonio pretendía dejar la puerta abierta para incrementar el número de enfiteutas que revertiesen en sus arcas.

Sin embargo, hasta el año 1827 el Real Patrimonio no volvió a activar el establecimiento de tiendas, al menos en las baronías valencianas de los Medinaceli. El 10 de diciembre de ese año, el Intendente

29 En ARV, Bailía B, leg. 33, exp. 417, pliego 7, sin foliar.

30 El artículo sexto de la Orden decía, "que acordado en esta forma el Estanco, no se permitirá la venta al por menor sino en los puestos públicos". En MARTín de BALMASEDA, F. (1823), op. cit., t. VI, p. 268.

31 La resolución de la Contaduría Patrimonial, fechada en 25 de enero de 1820, en ARV, Bailía B, leg. 33, exp. 417, pliego 7, sin foliar. 
General del Reino autorizaba al Ayuntamiento de Segorbe a solicitar ante el Real Patrimonio el establecimiento en la ciudad de una Alhóndiga de granos, seis tiendas de abacería y dos panaderías, con el objetivo de arrendarlas y poder alcanzar caudales suficientes para hacer frente a las contribuciones reales y a los adeudos provocados por la minoración de los bienes de Propios. La solicitud se cursaba el 25 de enero de 1828, provocando la hostilidad no solo del Duque de Medinaceli, sino también de los comerciantes de la ciudad ${ }^{32}$. La casa ducal volvió a apelar para defender sus intereses a las argumentaciones conocidas, aunque el desánimo y la indolencia parecían presidir cada vez más la estrategia de los agentes ducales, consecuencia de las escasas expectativas de éxito en el proceso judicial y de la postración en que habían quedado las dos tiendas señoriales en los últimos años ${ }^{33}$. Actitud muy diferente mantuvieron los comerciantes de Segorbe, que no se oponían tanto al estableci- miento de nuevas tiendas como a la pretensión del Ayuntamiento de dotarlas de carácter exclusivo.

La sucesión de acontecimientos en la apertura de tiendas parecía muy similar a la vivida en el año 1819, pero ahora el resultado iba a ser muy diferente. En pocos días se resolvería favorablemente la solicitud del consistorio segorbino, una sentencia que podía extenderse a otros ayuntamientos implicados en procesos semejantes, como sucedía en Benaguasil y Eslida. Sin embargo, los acontecimientos en estas dos poblaciones siguieron un guion muy diferente, debido al mayor énfasis mostrado por la casa ducal en la defensa judicial de sus intereses. En Benaguasil el Ayuntamiento había solicitado tres tiendas de abacería, que se sumarían a las dos que ya poseía el Duque. Mientras que en Eslida, que no contaba con ningún de establecimiento por la cortedad del vecindario, se solicitaba al Real Patrimonio la apertura de un tienda-taberna. En ambos casos la estrategia de la casa ducal fue la

32 ARV, Bailía E, exp. 3403.

33 En el año 1762, cuando las regalías todavía mantenían la efectividad de su carácter privativo, las dos tiendas se arrendaban por 10.020 reales anuales, sobre los 64.350 reales que suponía el total de los derechos dominicales y regalías. En 1806 ya solo alcanzaron un precio de 3.312 reales sobre los 105.195 reales del total. En el año 1827 el total ascendía a 67.500 reales, sin poder desglosar cada uno de los componentes, aunque podemos intuir que la cantidad pagada por las tiendas sería muy pequeña. En GÓMEZ BENEDITO, V. (2009): Conflicto antiseñorial y abolición del Régimen Feudal en Segorbe, Ayto. de Segorbe, Segorbe, p. 247. 
misma, dilatar de una forma exasperante el proceso judicial, con el objetivo de erosionar la determinación de sus oponentes y esperar un momento más propicio para sus intereses. Y los cambios se produjeron.

A comienzos de la década de los años treinta la calamitosa situación del país provocó un moderado giro en la política económica del gobierno, buscando una mayor libertad en los mercados. Entre las diferentes medidas que se fueron tomando estaba la Real Orden de 24 de febrero de 1831, que determinaba no corresponder "al Real Patrimonio en ese Reyno la facultad de dar en establecimiento tiendas de Mercería y otros puestos publicos de esa clase, y en consecuencia son nulos é insubsistentes los concedidos por esa Baylia general (...) sin perjuicio de lo mandado (...) acerca del establecimiento de Carnicerias" 134 . De esta forma se sobreseían los pleitos iniciados en Benaguasil y Eslida, pero también se anulaban las tiendas concedidas en Segorbe en el año 1828 y todas las anteriores establecidas en otras poblaciones de los dominios valencianos de los Medinaceli. Esa orden se completaba con otra posterior de enero de 1834 que decretaba la libertad de establecimientos para las carnicerías. Las nuevas órdenes podrían considerarse como beneficiosas para la estrategia emprendida por la casa ducal, al evitar un poderosísimo competidor en la pugna por la constitución de tiendas, panaderías, tabernas y carnicerías, pero la realidad era completamente distinta, puesto que a partir de ese momento la libertad para abrir ese tipo de establecimientos era completa y los posibles competidores mucho más numerosos.

\section{Pesos y medidas}

Si continuada e intensa fue la oposición del Duque al establecimiento de tiendas por el Real Patrimonio, no menos vehemente fue la actitud mostrada en la defensa de los sistemas de pesos y medidas, que de forma privilegiada mantenía en determinadas localidades como regalía. A comienzos del año 1828 el Ayuntamiento de Segorbe solicitó al Real Patrimonio la apertura de una alhóndiga de granos en la ciudad. La petición se englobaba en el conjunto de establecimientos que se habían demandado para poder

34 La Junta Patrimonial de Valencia intentó paralizar esa Real Orden, aduciendo que el término mercería solo afectaba al comercio de cosas menudas y de poco valor. Pero el gobierno de Madrid no aceptó los argumentos de la Junta, expidiendo el 12 de septiembre de 1832 una Real Orden en la que se asimilaban las tabernas, panaderías y puestos públicos de abacería a las tiendas de mercería. La Real Orden de 1831 en ARV, Bailía, Libros, n 6, fol. 43; el memorial elaborado por la Junta y enviado a Madrid para intentar paralizar la citada Orden en el mismo documento, fols. 132-147. 
hacer frente a las contribuciones generales. Pero a diferencia de lo ocurrido con tiendas y tabernas, en el caso de la alhóndiga la oposición del Duque fue mucho más firme. La explicación de esta diferencia en la actitud de la casa ducal radica en los intereses económicos en juego: el almudín o alhóndiga de granos del Duque venía a representar entre cuatro y cinco veces más ingresos en Segorbe que las tiendas señoriales $^{35}$.

El contencioso por preservar el carácter privativo del almudín en Segorbe no era nuevo, el Duque había mantenido sucesivos litigios con los vecinos que vendían granos directamente en sus casas, problema que se amplió cuando la Real Cédula de 15 de septiembre de 1814 no reintegró a los señores en sus derechos exclusivos. Pero la situación ahora planteada era mucho más grave, el establecimiento de una alhóndiga por el Ayuntamiento podía afectar a las ventas de cantidades mucho más importantes, aquellas relacionadas con el comercio del Camino Real de Aragón. Por esta razón, el Duque mantuvo un largo y costoso proceso judicial, aunque de resolución poco satisfactoria, porque en mayo de 1833 el Baile General de Valencia desestimaba su oposición y concedía al Ayuntamiento de Segorbe y a su Junta de Propios el establecimiento solicitado. La casa ducal interpuso apelación a la sentencia en primera instancia y ante su revocación por el tribunal valenciano, se dirigió a la Junta Suprema Patrimonial de Apelaciones de Madrid ${ }^{36}$.

En la Vall d'Uixó, la actuación del Duque con respecto a la alhóndiga fue muy diferente. La Villa había disfrutado desde el comienzo de la ocupación cristiana de los dos almudines existentes, uno en cada una de las dos parroquias. En el año 1828 el consistorio decidió solicitar al Real Patrimonio los correspondientes suplementos de títulos de establecimiento, para evitar posibles problemas con la Junta Patrimonial de Valencia, pero la maniobra tuvo un efecto contraproducente. Vista la demanda del consistorio, el Real Patrimonio estimó conveniente apropiarse de los dos almudines para arrendarlos posteriormente. En el subsiguiente desarrollo del expediente gubernativo ${ }^{37}$ compareció el

35 En el año 1806, último en el que se desglosaron los derechos dominicales, el arriendo del almudín suponía 10.560 reales anuales, mientras que las tiendas solo representaban 3.312 reales. Estas diferencias aumentarían posteriormente en favor del almudín. En Gómez BENEDITO, V. (2009), op. cit., p. 247.

36 El expediente de solicitud de establecimiento y los posteriores conflictos generados en ARV, Bailía E, Apéndice, exp. 782.

37 El expediente en ARV, Bailía E, Apéndice, exp. 873 
Duque como dueño baronal, pero sus alegaciones fueron puramente testimoniales, siendo desestimadas rápidamente. Para entender la diferente actitud del Duque en este contencioso, frente a los que estaba planteando en Segorbe, hay que tener en cuenta dos factores. Primero, el Duque nunca había dispuesto del dominio y gestión del almudín en la Vall d'Uixó, por lo que su apelaciones se dirigían más a defender un derecho genérico que a mantener un auténtico recurso económico. Segundo, los ingresos conseguidos por los dos almudines de la Vall d'Uixó eran muy inferiores a lo recaudado por el arriendo del almudín segorbino ${ }^{38}$. Muy diferente fue el comportamiento del Ayuntamiento de la Vall d'Uixó, quien sí defendió activamente la propiedad pleiteada, pero su empeño fue estéril, porque no pudo presentar los títulos justificativos requeridos, limitándose a fundamentar su argumentación en la posesión inmemorial, testimonio poco consistente ante el tribunal patrimonial. De esta forma, se adjudicaba el Real Patrimonio los dos almudines, a expensas de la segura confirmación de la Junta Suprema en Madrid.

No obstante, el desenlace final del contencioso de las alhóndigas de granos, tanto en Segorbe como en la Vall d'Uixó, fue muy distinto al que el proceso judicial había marcado y estuvo determinado, de nuevo, por la paulatina implantación de la legislación liberal en el ámbito económico. El 29 de enero de 1834 una Real Orden ${ }^{39}$ declaraba la libertad de venta, negociación y tráfico de harinas, trigo y otro tipo de granos, afectando directamente a la supervivencia de las alhóndigas que hasta ese momento se habían mantenido con carácter privativo o visto favorecidas por un mercado fuertemente regulado. Por esa razón, cuando en junio de 1834 se lea en el Ayuntamiento de Segorbe la Real Provisión ${ }^{40}$ por la que se ordenaba emplazar ante la Junta Suprema Patrimonial de Apelaciones a las partes del contencioso de la alhóndiga de granos, para presentar los argumentos y documentos considerados convenientes a sus intereses, la respuesta del consistorio será darse por enterado sin to-

38 La media de ingresos por el arriendo del almudín de la parroquia del Ángel Custodio en la Vall d'Uixó durante el quinquenio 1824-1828 ascendía a 1.730 reales, mientras que el de la parroquia de la Asunción solo llegaba a 311 reales. Medias calculadas a partir de los datos incluidos en ARV, Bailía E, Apéndice, exp. 873, fols. 7r-8r.

39 NIEVA, J. M. (1835): Decretos de la Reina nuestra Señora Doña Isabel II, tomo XIX, Imprenta Nacional, Madrid, pp. 40-41.

40 La Real Provisión se dictaba el 3 de enero de 1834. El expediente de apelación en Archivo General de Palacio (AGP), Bailía de Valencia, caja 7.126, exp. 1566. 
mar acuerdo alguno al respecto. La libertad de granos en vigor desde hacía cinco meses convertía en improductiva la anhelada alhóndiga y desatinado el mantenimiento de los autos judiciales. De la misma forma, tampoco tuvo ya demasiada trascendencia que el Real Patrimonio adquiriese el dominio de los alhóndigas de la Vall d'Uixót ${ }^{1}$. Pero esos perniciosos efectos para el Real Patrimonio también alcanzaron al Duque, que perdía la posición de ventaja que había mantenido en su regalía segorbina más preciada, el almudín.

De las regalías concernientes a los procesos de distribución y venta solo queda por remarcar el peso y mercado, conocido popularmente en Valencia como el Cántaro y Romana. En realidad, los ingresos económicos percibidos por la casa ducal de esta regalía se limitaban a la ciudad de Segorbe, donde se había cobrado desde el inicio de la conquista cristiana. Pero esta realidad no determinó la separación del Duque de los distintos litigios que se desarrollaron en otras poblaciones durante este período, reclamando en todas las ocasiones que se presentaron los derechos sobre el peso y mercado.

Evidentemente, el mayor empeño de la casa ducal por defender esos derechos se centró en la ciudad de Segorbe, donde el cántaro y la romana habían llegado a convertirse en uno de sus ingresos más relevantes $^{42}$. Y también uno de los más discutidos por la población. Desde el año 1814 los problemas para su percepción fueron crecientes, debido tanto a la negativa al pago de los vecinos, como a la pretensión del consistorio por adquirirlos. Tenemos noticias de la existencia de un expediente judicial iniciado por el Ayuntamiento de Segorbe en el que se disputaba al Duque el derecho de peso y mercado. El litigio

41 El Baile General de Valencia había declarado en junio de 1835 pertenecer al Real Patrimonio las alhóndigas de la Vall d'Uixó. Con posterioridad, se envió el expediente a la Junta Suprema de Madrid, quien lo devolvió a Valencia para admitir apelaciones, pero como éstas no se produjeron se decretaba por consentida la sentencia en febrero de 1836. En ARV, Bailía E, Apéndice, exp. 873, fols. 62r-77r.

42 En el año 1806, último en el que se desglosaron los derechos dominicales, el arriendo del cántaro y la romana supuso unos ingresos de 5.120 reales, casi el doble que las tiendas señoriales. En GÓMEZ BENEDITO, V. (2009), op. cit., p. 247. 
aún se mantenía vigente en el año $1835^{43}$ y tuvo como principal repercusión para la casa ducal una considerable merma en sus ingresos ${ }^{44}$. De forma excepcional, no tenemos constancia que el Real Patrimonio interviniese en el contencioso para hacer prevalecer sus derechos.

Muy distinto fue el desarrollo de los acontecimientos en la Vall d'Uixó. En esta villa el Duque había establecido enfitéuticamente los derechos del peso y mercado al municipio en el año 1616. Esta gracia señorial era uno de los capítulos de la concordia firmada con la población para mejorar la Carta Puebla de 1613 y conseguir repoblar la baronía. La ventaja económica que suponía para la villa disfrutar de los derechos de peso y merca- do era evidente, constituyéndose en los años veinte del siglo XIX como el principal ingreso de la Junta de Propios, muy por encima de los dos almudines ${ }^{45}$. La relevancia de estos derechos explica la decisión del consistorio de solicitar al Real Patrimonio los correspondientes suplementos de títulos de establecimiento, una demanda que se tramitó conjuntamente con la petición de los almudines. Y el resultado final fue el mismo que el ya relatado para las dos alhóndigas de granos: el Real Patrimonio decidió apropiarse de estos derechos para arrendarlos posteriormente al mejor postor. También en este caso la casa ducal compareció en el expediente judicial $^{46}$, aunque con mucha más determinación que en el contencioso

43 El conocimiento del conflicto se debe a diversas notas que aparecen en otros pleitos judiciales y sesiones del consistorio, pero no hemos podido localizar el expediente judicial concreto. Podemos conjeturar que el litigio se mantenía activo en el año 1835 porque en la sesión del Ayuntamiento de Segorbe de 18 de abril de ese año, se daba cuenta "de la devolución del Expediente de la Romana y decreto del Señor Gobernador Civil puesto en el mismo por el cual les piden los Datos á saber el motivo de haver dejado de pertenecer los Arbitrios de la Romana al Duque de Medinaceli". En AMS, sig. 3019/54, fol. 1833-1835, 75.

44 En la escritura de arriendo de los derechos dominicales y regalías de Segorbe en 1818, el arrendador expresa "las baxas que en la duracion del presente arriendo han tenido las regalias y drechos de Vuescencia en Segorbe y Benaguasil, pues que en el primero se han formado dos expedientes en vista de los Bandos y edictos publicados sobre la libertad de vender trigos sin sujecion al Almudin de Vuescencia, como de pertenecer á los Propios de dicha Ciudad los drechos del peso". En ARV, Protocolos, Carlos Pajarón, 7142, fol. $215 \mathrm{r}$.

45 La media de ingresos por el arriendo del cántaro y la romana de la parroquia del Ángel Custodio en la Vall d'Uixó durante el quinquenio 1824-1828 ascendía a 5.803 reales, mientras que el de la parroquia de la Asunción era de 5.454 reales. En ARV, Bailía E, Apéndice, exp. 984 , fol. 8.

46 El expediente en ARV, Bailía E, Apéndice, exp. 984. 
de los almudines. El montante económico en juego lo explica.

Tanto en Segorbe como en la Vall d'Uixó la disputa por los derechos de peso y mercado fue larga y compleja. No fue el caso de Benaguasil y la Pobla de Vallbona. En estas dos últimas localidades, los ayuntamientos habían incorporado los derechos de peso y mercado al reglamento municipal de propios y arbitrios, redactado a comienzos de los años sesenta del siglo XVIII. Desde entonces, esos derechos se habían venido cobrando como un arbitrio municipal más para hacer frente a los gastos de los ayuntamientos. Sin embargo, esa situación cambiaría a partir de 1817. En ese año un vecino de la Pobla de Vallbona había solicitado ante el Real Patrimonio el establecimiento del peso y mercado de la localidad. El propio vecino interrumpió la demanda cuando intervino el Ayuntamiento, que alegaba la pertenencia del cobro de ese derecho. Pero la solicitud había abierto las apetencias del Real Patrimonio, reclamando al consistorio los títulos de propiedad. El inicio del expediente administrativo también suscitó la incorporación de la casa ducal, invocando ser la dueña y se- ñora baronal de la población, pero sus argumentos fueron rápidamente desestimados. Igual suerte correría el Ayuntamiento, al plantearse que la inscripción en el Reglamento de Propios y Arbitrios no presuponía la titularidad de los derechos, perteneciendo estos a la Corona, al ser una de sus regalías. De esta forma, en marzo de 1818 se declaraba pertenecer al Real Patrimonio los pesos y medidas de la Pobla de Vallbona. Similares circunstancias concurrieron en Benaguasil, donde en septiembre de 1824 los mencionados derechos también pasaban a la Corona $^{47}$. No estamos hablando de cantidades económicas elevadas, poco más de cien libras anuales en ambos casos, pero sí debe remarcarse la determinación de la institución patrimonial en pelear cualquier tipo de propiedad o derecho en juego, por pequeño que fuese, y el escaso margen de maniobra de municipios y casas nobiliarias para poder defenderlos.

Pero la nueva legislación económica liberal todavía depararía nuevos cambios. La ley de 20 de enero de 1834 sobre la libertad de comercio de los objetos de comer, beber y $\operatorname{arder}^{48}$, puso contra las 556.

48 NIEVA, J. M. (1835), op. cit., tomo XIX, pp. 28-30. 
cuerdas las rentas percibidas por los derechos de peso y mercado. Tanto en las localidades donde se mantenía el litigio por los derechos entre las diferentes partes, como en aquellas otras donde prevaleció la autoridad del Real Patrimonio, la negativa al uso y pago de estos derechos fue cada vez más extendida. Sin embargo, y a diferencia de lo ocurrido con las tiendas señoriales - los almudines, el peso y mercado no llegaría a desaparecer. El nuevo estado liberal permitió a los ayuntamientos mantener esos derechos, con la pretensión de evitar fraudes en las transacciones $y$, sobre todo, de allegar recursos a las depauperadas haciendas municipales. $Y$ cuando una nueva ley suprima "los oficios ó cargas de Fiel medidor, Lonja, Correduría, Peso Real y demas que bajo cualquiera denominacion recaiga sobre el peso ó la medida, libertando á los pueblos de estos gravámenes" 49 , se dispondrá otra norma que permita su continuidad, aunque destacando el carácter voluntario de la utilización del peso y medida ${ }^{50}$.

\section{Tierras}

En este extenso listado de contenciosos y litigios en los que, de una $u$ otra forma, se vio implicada la casa ducal, como consecuencia de las solicitudes de particulares y ayuntamientos de nuevos establecimientos ante el Real Patrimonio, queda por examinar el concerniente a la demanda de tierras. En este último caso, las solicitudes de establecimientos fueron muy inferiores y prácticamente concentradas en la ciudad de Segorbe.

En Segorbe el derecho para establecer en terrenos incultos se encontraba en manos del Ayuntamiento, escenario ante el que la casa ducal siempre se mantuvo beligerante, aunque con resultados negativos. $Y$ no mejor desenlace obtuvo el Real Patrimonio en su intento por obtener ese derecho ${ }^{51}$. Pero esta situación cambiaría definitivamente durante el Sexenio Absolutista, teniendo su primer y más arduo contencioso en el litigio protagonizado por dos vecinos de Geldo. Los hermanos Alayrach habían solicitado en

49 Real Orden de 14 de julio de 1842. En Colección de las leyes, decretos y declaraciones de las Cortes (1843), tomo XXIX, Imprenta Nacional, Madrid, p. 45.

50 El 18 de marzo de 1844, una Real Orden permitiría a los ayuntamientos el arriendo de pesos y medidas, pero observando "que ni los vecinos ni los forasteros han de tener la obligación de valerse del peso y medida del arrendador". En Colección de las leyes, decretos y declaraciones de las Cortes (1844), tomo XXXII, Imprenta Nacional, Madrid, p. 436.

51 Para obtener un conocimiento detallado del conflicto entablado por el derecho a establecer terrenos incultos en Segorbe véase Gómez BenediTo, V. (2009), op. cit., pp. 71-81. 
junio de 1815 al Real Patrimonio la nada despreciable cantidad de 113 cahizadas de tierra inculta en término de Segorbe, con el propósito de transformarla para el cultivo del trigo y la vid ${ }^{52}$. Iniciado el proceso administrativo en la Bailía de Murviedro, el Ayuntamiento de Segorbe comisionaba a sus síndicos para que "protesten en el acto qualquiera derecho que reside en la Ciudad, como señora de montes y aguas, para que no le pare perjuicio"53. Respondía el Procurador del Real Patrimonio ordenando "que al Ayuntamiento de la Ciudad de Segorve se pase el competente oficio para que se abstenga de conceder establecimientos de terrenos incultos en su termino" 54 . Finalmente, en agosto de 1819 se declaraba al Real Patrimonio propietario de los terrenos incultos disputados y concedía los establecimientos solicitados.

En el pleito judicial descrito, la intervención de la casa ducal fue puramente testimonial, muy distinta a la que ejercería una década después. En el año 1825, el Duque planteó una oposición activa al establecimiento de tierras pedido ante el Real Patrimonio por Mateo
Martínez $^{55}$. Pero fue la solicitud del presbítero segorbino Severo Polo la que centró las energías de la Contaduría del Duque en Valencia, llegando incluso hasta la Junta Suprema de Apelaciones en Madrid. Severo Polo había solicitado el establecimiento de 160 jornales de terreno inculto, oponiéndose el Duque como señor de Segorbe. Viendo los resultados cosechados, seguir fundamentando jurídicamente la posición del Duque en la donación real del señorío y las concesiones dadas a los señores feudales tras la expulsión de los moriscos, parecía completamente ineficaz. Era absolutamente necesario construir un nuevo baluarte argumentativo. Y en esa dirección se encaminó la propuesta de Luis Blanch, abogado del Duque. Blanch admitía que las regalías competían al rey por derecho de soberanía y no podían enajenarse, pero calificaba a estas regalías como mayores o de corona y las diferenciaba de otras menores o también denominadas de erario. Estas segundas, a las que pertenecía el derecho a establecer tierras baldías, podían ser adquiridas por los pueblos y sus dueños, por Real Orden de 1 de agosto de 1739 expedida por la Real Junta de Baldíos.

52 ARV, Bailía E, exp. 2536.

53 Acuerdo tomado en la sesión del Ayuntamiento de Segorbe de 14 de septiembre de 1815. En AMS, 3015/50, fol. 1815-47r.

54 ARV, Bailía E, exp. 2536, fol. $11 \mathrm{v}$.

55 ARV, Bailía E, exp. 3221, fol. 63r. 
Pero, a pesar de la precisión y claridad expositiva de Blanch, el Baile General de Valencia decretaba "que la facultad de establecer terrenos valdios en la ciudad y termino de Segorve toca y pertenece al Real Patrimonio" 56 .

Fuera de la ciudad de Segorbe, las solicitudes presentadas al Real Patrimonio de establecimiento de tierras incultas fueron muy escasas. Destacaremos dos expedientes en los que el principal objetivo del Duque fue entorpecer la vía gubernativa para dilatar su resolución. Y de hecho lo consiguió, porque en ninguno de los dos casos se llegó a una sentencia definitiva.

El primero de ellos se refiere a la villa de Eslida, donde un particular había solicitado en el año 1827 al Real Patrimonio 56 jornales de tierra poblada de alcornocales ${ }^{57}$. El Ayuntamiento de la Villa se opuso a la solicitud argumentando que los alcornocales requeridos habían sido establecidos por el Duque a la población tras el extrañamiento morisco, como medio para satisfacer los gastos y cargas más esenciales. Por esta razón, el consistorio se dirigía al Baile General, solicitando el suplemento de títulos sobre los citados alcornocales, declarando que la negativa a su demanda podría tener nefastos efectos sobre la población, al no disponer la Villa prácticamente de bienes propios y ser los arbitrios reconocidos de muy escasa cantidad y calidad. El problema para el consistorio surgió cuando el Duque se incorporó al proceso judicial, porque no pudo demostrar documentalmente el supuesto establecimiento del siglo XVII y, como ya sabemos, no bastaba con la presentación del Reglamento de Propios y Arbitrios para certificar judicialmente la titularidad de un bien o derecho. El Duque aprovecharía este contratiempo para dilatar el proceso, pidiendo que se le remitiesen los autos y ralentizando exasperantemente su devolución, hasta el punto de que en junio de 1834 el tribunal patrimonial exigía imperiosamente a la casa ducal su personación en la causa para continuar el pleito.

El otro expediente que remarcamos alude al lugar de Fondenguilla. Esta población intentó aprovechar el notable poder exhibido por el Real Patrimonio valenciano para mejorar sus ingresos. En el año 1826 el Ayuntamiento solicitaba las hierbas del término para atender a los gastos municipales, puesto que "por la cortedad de sus Propios no pueden atender a las dotaciones de maestro de primeras letras y Cuaresma" ${ }^{\prime 58}$. En esta ocasión la

56 ARV, Bailía E, Apéndice, exp. 587.

57 El expediente en ARV, Bailía E, Apéndice, exp. 818.

58 El expediente en ARV, Bailía E, Apéndice, exp. 982. 
respuesta del Duque fue mucho más enérgica, porque desde la constitución de la baronía las hierbas se habían arrendado conjuntamente junto con el resto de regalías y derechos dominicales. Pocas posibilidades de éxito debió vislumbrar el consistorio en su petición, desistiendo de su empeño pocos meses después de la apelación del Duque. Sin embargo, el Procurador Patrimonial se negó a que se sobreseyesen los autos judiciales, como exigía el Duque, instando que se reconociese al Real Patrimonio como dueño de las hierbas del término. También en este caso las argucias de los abogados del Duque imprimieron lentitud al proceso, estando todavía en junio de 1835 sin sentenciar.

Estos dos expedientes de establecimiento nunca se resolverían, al igual que otros muchos expuestos en las últimas páginas, porque diferentes órdenes promulgadas por el gobierno en la segunda mitad de la década de los años treinta llevaron al Real Patrimonio prácticamente a su extinción. Un Real Decreto de noviembre de $1835^{59}$, promulgado en palabras del Gobierno para premiar la lealtad de Cataluña, Valencia y Mallorca en la guerra contra los carlistas, disponía la libertad para construir en esos territorios molinos, hornos o cualquier otro tipo de artefactos, y de abrir al público tabernas, mesones, posadas, carnicerías, panaderías y demás tipos de tiendas. El nuevo Decreto completaba a los dos anteriores de enero de 1834, ratificando la libertad de comercio y establecimientos y sembrando la inquietud entre los enfiteutas del Real Patrimonio por la más que previsible competencia. Pero la institución patrimonial todavía mantenía el privilegio de personarse como juez y parte en los procesos judiciales donde se dirimiesen asuntos de su incumbencia, privilegio que también desaparecería escasamente un año después. Una Real Orden de 29 de septiembre de 1836, establecía la abolición de la Junta Suprema Patrimonial de Apelaciones y los tribunales privilegiados de las Reales Casas, debiéndose pasar a los juzgados ordinarios las causas civiles y criminales pendientes en aquellos ${ }^{60}$. Aun cuando la férrea oposición de la Junta Patrimonial de Valencia hizo necesario la promulgación de varias disposiciones posteriores para clausurar definitivamente el tribunal patrimonial en Valencia ${ }^{61}$, ya no se litigarán desde aquella fecha contenciosos sobre propiedades o

59 Real Decreto de 19 de noviembre de 1835. En ARV, Bailía, Libros, n 7, fol. 77.

60 Real Orden de 29 de septiembre de 1836. En ARV, Bailía, Libros, n 7, fol. 121.

61 Reales Órdenes de 31 de enero y 24 de mayo de 1838. Sobre esta cuestión véase GARCÍA MONERRIS, E. (1983), op. cit., p. 105. 
derechos del Real Patrimonio en los dominios valencianos de la Casa de Medinaceli.

Desmantelada la jurisdicción privativa del Real Patrimonio e implantada la libertad de comercio, quedaba a la Junta Patrimonial la enojosa tarea de administrar unos establecimientos enfitéuticos cuyos propietarios se encontraban en permanente estado de irritación, por cuanto la competencia les había llevado a una delicada situación económica, demandando la mayoría una rebaja del canon annuo en consonancia con la nueva situación 0 , incluso, la revocación del contrato. Tan inestable relación se concluía con el Decreto de las Cortes de 29 de enero de 1837, por el que se restablecía el Decreto de 19 de julio de 1813, suprimiendo los privilegios exclusivos, privativos y prohibitivos que estuviesen bajo el Real Patrimonio y, en consecuencia, quedando libres sus enfiteutas del pago de pensiones y demás gravámenes impuestos en las escrituras de establecimiento obtenidas ${ }^{62}$.

De esta forma, prácticamente se liquidaban los intereses del patrimonio regio en los dominios valencianos de la casa ducal, finiquitando una relación de escasamente cuarenta años, pero muy intensa. Durante ese breve período de tiempo, la incorporación del Real Patrimonio a la disputa por las rentas en estas baronías había alterado significativamente el enraizado contencioso entre los pueblos y la casa ducal, condicionando las estrategias de actuación de ambas partes y modificando las rentas percibidas, tanto en cantidad como en su estructura.

\section{Conclusiones}

La actuación patrimonialista de la Corona en el período final del Antiguo Régimen tuvo profundas repercusiones económicas sobre los señoríos valencianos, en algunos momentos y lugares más relevantes incluso que las provocadas por los movimientos de resistencia y protesta antiseñorial. La explicación a esta dinámica se encuentra en la propia configuración de la renta señorial valenciana, muy dependiente de las regalías. En los dominios valencianos de los Medinaceli, las rentas percibidas por los derechos privativos o regalías venían a suponer en esa época entre la cuarta parte y un tercio del total de los ingresos nobiliarios. Y al valorar estas proporciones debe tenerse en cuenta que muchos de los monopolios señoriales, conformados gracias a los derechos privativos, ya se habían enajenado o perdido. En baronías de la Pobla de Vallbona, Dénia, Xàbia y Palma y Ador, el señor había cedido en el pasado todos los monopolios, bien como medida para que las poblaciones pudieran hacer frente a los 
elevados censos con los que se encontraban cargadas, como gracia para conseguir encauzar algún conflicto o, simplemente, por desidia e indolencia de los agentes señoriales en su tarea de control sobre la instalación de molinos, hornos o almazaras por particulares. En el resto de señoríos el panorama venía marcado por una enorme diversidad. En poblaciones como Segorbe, Geldo, la Sierra de Eslida o Beniarió la casa ducal había conservado pocos monopolios o de escasa significación económica; en la Vall d'Uixó solo había enajenado la carnicería y la almazara; mientras que en señoríos como Benaguasil, El Verger - Chiva los derechos privativos se ejercían de forma completa. Esta circunstancia permite entender por qué el conflicto de las regalías no se limitó a la disputa entre señores y el Real Patrimonio, teniendo también un protagonismo significativo tanto los ayuntamientos como un número no despreciable de particulares.

La política de recuperación de rentas y derechos por parte de la Corona se inició con la llegada misma de la dinastía borbónica, aunque no tendría verdadera trascendencia hasta el año 1816, cuando Fernando VII termine de configurar el Real Patrimonio valenciano como una posesión particular. Hasta ese momento, la legislación de las Cortes de Cádiz relativa a la supresión de los derechos privativos había ocasionado un rápido crecimiento en la construcción de molinos, hor- nos y almazaras por distintos particulares, provocando también la rotunda reacción de los señores. Pero el conflicto se complicará cuando en el año 1816 la Corona asuma una política clara y contundente de recuperación patrimonial.

El nuevo escenario afectará significativamente a los señores. Acostumbrados a litigar con los pueblos, ahora se encontraban con un competidor mucho más duro e implacable, el propio monarca. Y con un notable agravante, ¿̇podían enfrentarse abiertamente a la Corona, su aliado natural, cuando era ésta quien les permitía mantener una posición social privilegiada? La respuesta resulta obvia. Los nobles solicitaron en reiteradas ocasiones el favor real, pero no encontraron la respuesta esperada. Y tampoco tuvo mejor resultado el recurso al contencioso judicial, por cuanto el monarca se había erigido en juez y parte en los litigios patrimoniales. A pesar de las dificultades planteadas, el duque de Medinaceli se personó como parte afectada en todos y cada uno de los expedientes en los que diferentes particulares solicitaban al Real Patrimonio la concesión de establecimientos sobre sus dominios. En ningún caso las resoluciones dictadas por los órganos administrativos y judiciales fueron favorables a la casa ducal, ocasionándole un grave perjuicio económico. Los nuevos enfiteutas del Real Patrimonio abrieron molinos, hornos o almazaras en las baronías del Du- 
que, rompiendo el ya endeble sistema monopolístico señorial y, en consecuencia, perdiendo la casa ducal el principal aliciente para conseguir unos buenos precios en las subastas de los contratos de arriendo.

Pero la evolución de los acontecimientos acabaría perjudicando no solo a los señores, también a los ayuntamientos que habían conseguido en el pasado algunas regalías y al mismísimo Real Patrimonio. Desde comienzos de la década de los años treinta del siglo XIX, la progresiva liberalización del comercio interior, que afectaba al estanco de tiendas y a los pesos y medidas, así como el desmantelamiento de la jurisdicción privativa del Real Patrimonio, provocaría la completa desaparición de los derechos privativos, exclusivos y prohibitivos. La nueva legislación liberal de los años treinta había acabado con la posición preeminente del Real Patrimonio, pero esta circunstancia no pasaba de ser un magro consuelo para el duque de Medinaceli, porque la ausencia del tenaz competidor que en los últimos años le había disputado las regalías, no le devolvieron los sustanciosos ingresos que aquellas le habían proporcionado a sus antecesores durante centurias.

\section{Biblografía}

ARDIT LUCAS, M. (1993): "Señores y vasallos en el siglo XVIII valenciano", en SERRANO E. y SARASA E. (eds.), Señorío y feudalismo en la Península Ibérica (siglos XII-XIX), Fdo. el Católico, Zaragoza, vol. II, pp. 249-274.

BRANCHAT, V. (1784-1786): Tratado de los derechos y regalías que corresponden al Real Patrimonio en el Reino de Valencia y de la jurisdicción del Intendente como subrogado en lugar del antiguo Bayle general, Imprenta de Joseph i Tomás de Orga, Valencia.

CARRASCO MARTíNEZ, A. (1996): "Modernización o adaptación: los cambios en la administración señorial durante el siglo XVIII", en Gonzalo Anes (coord.), El mundo hispánico en el siglo de la luces. Coloquio internacional unidad y diversidad en el mundo hispánico del siglo XVIII, Univ. Complutense, Madrid, vol. I, pp. 557-573.

CATALÁ SANZ, J. A. (1995): Rentas y patrimonios de la nobleza valenciana en el siglo XVIII, Siglo XXI, Madrid.

Coleccion de los Decretos y Órdenes que han expedido las Córtes Generales y Extraordinarias desde .. Mandada publicar de orden de las mismas, tomos I a X (18201823), Imprenta Nacional, Madrid. Colección de las leyes, decretos y declaraciones de las Cortes y de los Reales Decretos, ... expedidos por las Secretarias del Despacho desde ..., tomos XXII a XXIX (1837-1843), Imprenta Nacional, Madrid.

Colección de las leyes, decretos y declaraciones de las Cortes, y de los Reales Decretos, ... expedidos 
por los Respectivos Ministerios desde ..., tomos XXX a XXXV (18431846), Imprenta Nacional, Madrid. GARCÍA MONERRIS, C. (1983): "Fernando VII y el Real Patrimonio (1814-1820): las raíces de la 'cuestión patrimonial' en el País Valenciano", Estudis d'Història Contemporània del País Valencià (EHCPV), $\mathrm{n}^{\circ} 4$, pp. 33-66.

GARCÍA MONERRIS, E. (1983): "Real Patrimonio y resistencias antifeudales en el País Valenciano (1834-1843)", EHCPV, n 4, pp. 99-132.

GARCÍA MONERRIS, C. Y E. (2004): "La Nación y su dominio: el lugar de la Corona", Historia Constitucional, n 5, pp. 161-190.

GARCÍA MONERRIS, C. Y E. (2015): Las cosas del rey. Historia política de una desavenencia (1808-1874), Akal, Madrid.

GÓMEZ BENEDITO, V. (2009): Conflicto antiseñorial y abolición del Régimen Feudal en Segorbe, Ayto. de Segorbe, Segorbe.

GÓMEZ BENEDITO, V. (2015): Declive y liquidación de los dominios valencianos de la Casa de Medinaceli, tesis doctoral, Universitat Jaume I, Castelló.

MARTíN DE BALMASEDA, F. (18181824): Decretos del rey don Fernando VII, ... Se refieren todas las reales resoluciones generales que se han expedido por los diferentes Ministerios de ..., tomos I a VII, Imprenta Real, Madrid.
NIEVA, J. M. (1835-1837): Decretos de S.M. la Reina Doña Isabel II, dados en su real nombre por su augusta madre la Reina Gobernadora, y reales ordenes, resoluciones y reglamentos expedidos por las secretarias del despacho universal desde ..., tomos XIX a XXI, Imprenta Real, Madrid.

Ordenanza de 4 de julio de 1718. Para el establecimiento, e instruccion de Intendentes y para Tesorero General, pagadores y contadores de los Exercitos, y Provincias (1720), Juan de Ariztia, Madrid.

PESET, M., GRAULLERA, V. Y MANCEBO, M. F. (1987): "Plets, senyories i propietat a la València del segle XVIII", Estudis d'Història Agrària, n 6, pp. 203-239.

RUIZ TORRES, P. (1984): "Los señoríos valencianos en la crisis del Antiguo Régimen: una revisión historiográfica", Estudis d'història contemporània del País Valencià (EHCPV), $n^{\circ}$ 5, pp. 23-79.

SANZ ROZALÉN, V. (2000): Propiedad y desposesión campesina. La Bailía de Morella en la crisis del régimen señorial, Fundación Instituto de Historia Social, Valencia.

WINDLER, CH. (1995): "Las reformas administrativas de la aristocracia española en el contexto del absolutismo reformista", Historia Social, $n^{\circ} 23$, pp. 79-99. 